\title{
WHAT IS THE ROLE OF THE PRINCIPAL IN PROMOTING GOOD RELATIONSHIPS WITH AND AMONG THE STAFF?
}

Chairman: Robert Lloyd, Vice Principal, White Pine High School, Ely, Nevada

Discussants:

Harold Mescher, Principal, High School, Cairo, Illinois

George L. Reiss, Principal, Wall Township High School, Belmar, New Jersey

\section{Summary of the presentation made by GEORGE E. MILLER}

ROMOTING good staff relations in schools was rather unheard of in early school administration. The relationship of staff to administration was usually one of independence. There was direction, but it was authoritarian and very dogmatic. Douglass in his book Organization and Administration of Secondary Schools presents six points why Democratic Administration is the key to good principal-staff relations:

1. It is the teacher's right

2. It makes for better relationships

3. It stimulates teacher growth

4. It results in better administration and teaching

5. It relieves, to some extent, overburdened administrators

6. It teaches democratic living to teacher, pupil, and administrator

In today's high school, the principal must work with his staff more than ever to accomplish the aims of modern education. No school can ever function or accomplish quality education when the planning is a one-way street with only the principal as the sole director. It is a fact that, when the staff has a voice in the planning of the school program, much more interest and cooperation will be given and the end result will be that all the staff will do a much better job. Many principals make a huge mistake when certain duties are delegated to members of their staff and then continue to look over their shoulders to see if the task is being done. When this happens, the staff takes little or just token interest in the assigned area.

Far too many principals criticize teachers in the presence of others and many times forget the human element involved. When we find problems with teachers, a private conference is the only way to solve the issue. Some administrators still take the route that, when some problem arises with a few people, they call a meeting of the entire staff and talk in general terms leaving all teachers with the question in their minds, "Does he mean me?"

George E. Miller is Principal of North Little Rock Senior High School, North Little Rock, Arkansas. 
The once popular song "The Little Things Mean a Lot" is so true in principal-staff relations. Principals should always create enough personal charm so that their staffs will never hesitate to discuss problems with them. I have found that, when the administrator can grant some small personal requests to his staff, better teaching results. More important, if the principal will exercise tact, sympathy, friendliness, and fairness, he is well on the way to having a good working relationship with his staff.

To point out what has been said, I refer to a number of surveys on what teachers say about principal-staff relationships. Teachers have said over and over again that the three things which are of the most importance are: (1) Confidence in the principal in respect to his leadership; (2) Cooperation among all the staff members; and (3) Esprit de corps and friendly atmosphere between teachers and administrator. The role of the principal in promoting good relationships with and among the staff becomes one key to the success of quality education in our schools.

\section{Summary of the presentation made by LESTER W. ANDERSON}

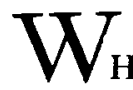

be improved. When teacher morale is high, students will also make greater achievement. ${ }^{1}$ In light of this fact, it is important that attention be given to characteristics or factors which are related to high teacher morale. The following factors are presented, therefore, as guides to principals interested in developing good working relationships with their faculties.

The high-school principal determines, to a great extent, the "climate" of operation within his school. Teachers are quick to sense the moods, values, and desires of the administrator. It can also be assumed that teachers are generally anxious to meet the expectations of the principal. Herein lies the key to the role of the principal in developing good relationships with his faculty.

If the principal demonstrates by his own behavior that he is willing to work cooperatively with others and that he thinks it is important for teachers to do the same, it is likely that teachers will respond in a manner compatible with the expectations of the principal. There must be a genuine desire on the part of the principal to behave in a cooperative manner, however, for it is very easy for teachers to detect any inconsistency in what the principal suggests and the way in which he behaves. One might think of it in terms of the slogan, "What you are speaks so loudly, I can hardly hear a word you say!"

${ }^{1}$ Lester W. Anderson, "Teacher Morale and Student Achievement," Journal of Educational Research, May 1953, p. 693-8.

Lester W. Anderson is Associate Professor of Education in the School of Education, University of Michigan, Ann Arbor, Michigan. 
Teachers must also have confidence in the ability of the principal to understand and assist them with instructional problems. A principal who is well informed concerning curriculum matters and who is a master teacher himself will be more highly regarded than one of less ability.

Ability to perform skillfully is not adequate alone. It is also important that the principal demonstrates a continuing interest in classroom activities of his teachers. Observations made by the principal relating to a particular project or class activity personalizes the concern of the principal for the instructional activities of his teachers.

It would be still better if the principal would be well enough acquainted with the teachers and their activities so that he might inquire on some of the more significant outcomes, individual student progress, or their future plans. Teachers will soon recognize sincere interest in their teaching, and they will then be more willing to discuss school matters.

Principals must also cultivate a positive approach with teachers. Some years ago, there was a popular song with the theme, "Accentuate the Positive-Eliminate the Negative." This could well be the slogan for administrators to follow. Research studies have demonstrated that greater motivation results from praise for a job well done rather than from punishment or criticism of one's failures and weaknesses. If every teacher is made to feel important because of praise for a job well done, good rapport is quite likely to be forthcoming. At least, the principal who practices this approach is likely to have better relationships with his teachers than is the principal who is constantly criticizing the faculty for not getting the job done effectively.

Teachers need opportunities to become identified with other teachers in working towards common goals. It is the responsibility of the principal to make such opportunities readily available. One of the most widely used techniques in working with the total faculty is through a regular "faculty meeting." These meetings can be very effective if they center on teacher problems rather than the principal and his problems. Faculty meetings which are organized around instructional problems give teachers an opportunity to identify themselves with the rest of the faculty in the solution to common goals.

It is also important for high teacher morale so that teachers have confidence in their fellow teachers. Most everyone wants to be proud of his school. It is generally recognized that the quality of the faculty determines, to a great extent, the quality of the school. Teachers may not always have the most modern building and facilities, but they may still have great pride in the school if they think there is a good faculty.

Planning instruction around a common instructional theme, such as "Democratic Heritage" is sometimes used effectively to unite all teachers on a common objective. Use of faculty committees to solve special problems gives teachers an opportunity to work together. There is no substi- 
tute for face-to-face working relations of the staff in providing opportunities to understand each other and to develop a feeling that each member is making a contribution to the goals of the entire group.

Another basic principle in establishing good relationships is that the intellectual ability of everyone is utilized appropriately. People with ability and talent want to use them constructively. The high-school principal should be observant of any unusual talents present in his staff. It may be that an individual's talent is limited, but most everyone has some special talent which can be utilized.

For reasons quite irrelevant, teachers are sometimes assigned to supervise certain extracurricular activities even though the teacher may have little ability or experience along these lines. It is very probable that such an assignment under these conditions will result in failure or a mediocre performance by the teacher. It is extremely doubtful that such an experience will contribute much to the teacher's mental health or to the personal relationships between that teacher and the principal.

A final concern is the social relationships of the principal with the faculty outside of school. It is difficult to establish recommendations in this area and, yet, it can be a significant element in developing desirable relationships between the principal and the faculty. It is a fairly safe assumption that practically all teachers would enjoy an invitation to the home of the principal. Both the principal and his wife might also find this to be a very rewarding event. Open-house affairs when a faculty is large is used frequently. Smaller faculties might rather be entertained at dinner, a bridge party, or some other type of small group affair. It is not necessary for the principal and his wife to be "social butterflies," but it is desirable that they be socially minded.

No doubt there are many additional factors or practices which could be identified which are equally important to the development of good relationships with and between the staff. This brief summary of selected factors is not intended to be an all-inclusive review. Rather, an attempt was made at presenting a few ideas which might be useful in this important role of the high-school principal. There is considerable opinion to support the idea that the success of a principal in establishing proper relationships with his faculty might very well be the crucial element in the success of his school. All principals are urged to give this problem their careful consideration. 